\title{
A LEITURA ARENDTIANA DA FACULdADE Do Juízo KANTIANA
}

(The Arendtian reading of the Kantian faculty of judgement)

Geraldo Adriano Emery Pereira *

Resumo: Este texto detém-se sobre um tema polêmico no contexto da obra da filósofa Hannah Arendt - a faculdade do juízo. A análise gira em torno da demonstração do modo como as peculiaridades da crítica do gosto kantiana são apropriadas por Arendt, numa leitura política desta faculdade. $\mathrm{O}$ artigo ensaia num primeiro momento uma apresentação do juízo de gosto; em seguida aponta os elementos que são apropriados por Arendt e sua leitura política. Deste modo se apresenta uma justificativa teórica para a apropriação arendtiana da faculdade do juízo de gosto kantiana, mostrando que, apesar de seu caráter "sui generis", ela é capaz de revelar aspectos importantes da própria realidade política.

Palavras chaves: Faculdade do juízo, política, sensus communis, juízo de gosto.

Abstract: This paper draws attention to a polemic subject in the context of the work of the philosopher Hannah Arendt - The faculty of judgement. The analysis brings into focus the way the characteristics of Kant's critique of taste have been used by Arendt in a political interpretation of that faculty. After explaining the Kantian judgement of taste, the paper points out the elements which have been appropriated by Arendt and shows her political reading of them. It proposes so a theoretical justification of the Arendtian use of Kant's analysis of judgement of taste, making clear that, in spite of its "sui generis" character, it is able to uncover important aspects of political reality itself.

Key words: Faculty of judgement, politics, sensus communis, judgement of taste.

\footnotetext{
* Mestre em Filosofia Social e Política/UFMG. Professor de Filosofia do Colégio de Aplicação da Universidade Federal de Viçosa. Artigo submetido a avaliação no dia 03/12/2010 e aprovado para publicação no dia 11/05/2011.
} 


\section{Introdução}

$\mathrm{H}$ annah Arendt possui em seu pensamento uma motivação para o seu exercício intelectual que é o pensar politicamente. Um desafio, uma ousadia; para muitos, uma afronta a concepções e conceitos há muito consolidados na história da filosofia. Um tema polêmico na obra arendtiana é a sua leitura sui generis da primeira parte da Crítica da faculdade do juízo, do filósofo Immanuel Kant. Ao que nos parece, a importância que a categoria da aparência recebe na obra de Hannah Arendt, não só numa fenomenologia da ação, mas também em uma "ontologia" do político justifica e torna razoável a sua leitura da obra de Kant.

Salienta-se aqui que Hannah Arendt não quer subverter a obra do filósofo de Königsberg, mas por uma reflexão estética, tenta apontar para uma racionalidade política que se estruture em torno da pluralidade que é própria à aparência e, consequentemente, ao modo humano de estar e ser no mundo. Uma racionalidade que possa pensar politicamente.

\section{A compreensão do juizo reflexionante}

Para alcançar êxito neste empreendimento, que é colocar em evidência a apropriação de Arendt, é necessário delimitar o que Kant estabelece como juízo reflexionante, pois é esse domínio da faculdade do juízo que será apropriado por Arendt em suas reflexões e aproximações políticas do juízo estético kantiano.

No desenvolvimento do sistema kantiano vai sendo construída uma noção de juízo que, aos poucos, ganha contornos que vão conferindo a esta faculdade um espaço entre as faculdades superiores de conhecimento. $\mathrm{O}$ juízo, tratado pela primeira crítica, diz respeito a uma atividade de caráter lógico, a princípio determinante, de conexão de um predicado a um objeto. Um tipo de operação de aplicação do conceito ao particular, isto é, de caráter determinante. Entretanto, vemo-nos diante da imensa, para não dizermos infinita, multiplicidade de coisas, fenômenos, ou seja, de particulares, que em determinadas circunstâncias escapam à generalidade do conceito, nesse caso, tem-se o particular à mão, mas não o universal, ou seja, o conceito dado, ao qual numa operação gnosiológica se subsumiria o particular. Frente a essa situação peculiar, mas não pouco corriqueira, Kant percebe a necessidade de uma faculdade judicativa, mas capaz de articular um movimento oposto ao movimento de conexão do juízo determinante. A faculdade do juízo, nessa situação, é reflexiva, pois não possui um universal ao qual um particular deveria ser subsumido, mas possui apenas o particular, para o qual um universal deverá ser encontra- 
do. Ao juízo, atuando nessas condições dá-se o nome, no sistema kantiano, de juízo reflexionante.

A faculdade do juízo em geral é a faculdade de pensar o particular como contido no universal. No caso deste (a regra, o princípio, a lei) ser dado, a faculdade do juízo, que nele subsume o particular, é determinante (o mesmo acontece se ela, enquanto faculdade de juízo transcendental, indica a priori as condições de acordo com as quais apenas naquele universal é possível subsumir). Porém, se só o particular for dado, para o qual ela deve encontrar o universal, então a faculdade do juízo é simplesmente reflexiva (KANT, 1995, p. 23).

Para podermos compreender e até tentarmos justificar - acrescentando talvez até elementos de nossa parte - o modo que torna o juízo reflexivo em seu uso estético atrativo a Arendt, indicaremos algumas características que julgamos de grande importância para uma apropriação política dessa faculdade em seu uso estético.

Como vimos há pouco, a faculdade do juízo tratada por Kant na terceira crítica, de início, evidencia a existência de dois domínios dessa faculdade: o determinante e o reflexivo ${ }^{1}$. Entretanto, o juízo reflexivo é uma definição geral de juízo que, a princípio, prescinde de seus dois usos distintos: o estético e o teleológico, sendo que o estético ainda se subdivide em juízo do belo e do sublime. A faculdade do juízo simplesmente como faculdade do juízo reflexivo trata exclusivamente com a multiplicidade dos particulares. É esta a preocupação de Kant, portanto a relação com esse número imenso de particulares requer no sistema da crítica kantiana, uma faculdade que os trate, que lide com eles.

A primeira crítica estabeleceu a possibilidade de conceituar pelo estabelecimento do processo das condições de possibilidade do conhecimento. A segunda crítica evidenciou a liberdade e, com isso, a possibilidade da moralidade a partir de um outro uso da razão, não o teórico, mas o prático. Entretanto, a multiplicidade fenomênica é marcada por inúmeras particularidades, que não são necessariamente abordadas na universalidade do conceito ${ }^{2}$ construído pela razão teórica, ou seja, subsumido pelo juízo determinante.

\footnotetext{
${ }^{1}$ A compreensão de juízo em Kant pode, portanto, ser lida sob essas duas perspectivas, o juízo determinante que articula conceitos e o reflexivo que compara e analisa representações. Allison (2001) cita a primeira Introdução da Crítica da Faculdade do Juízo para fazer a seguinte afirmação: "Judgment can be regarded either as mere[ly] an ability to reflect, in terms of a certain principle, on a given representation so as to [make] a concept possible, or as an ability to determine an underlying concept by means of a given empirical representation. In the first case it is the reflective, in the second the determinative faculty of judgment" (ALLISON, 2001, p. 15).

${ }^{2}$ Sobre a atividade da faculdade do juízo reflexivo é muito elucidativa a seguinte passagem que consta na segunda parte da Crítica, "O juízo teleológico": "Contudo a faculdade de juízo reflexiva deve subsumir sob uma lei que ainda não está dada e por isso é na verdade somente um princípio da reflexão sobre objetos, para os quais e de um modo
} 
Por não fazer parte desse princípio de universalização conceitual, a faculdade judicativa que lida com particulares e sua multiplicidade fenomênica não pretende estabelecer um procedimento teórico, gnosiológico, mas como Kant a define, uma reflexão. Assim, o juízo reflexivo, como elemento constitutivo do sistema da crítica kantiana, reivindica para a sua possibilidade um princípio a priori, para que possa ser legítima sua atividade como faculdade autônoma em seu exercício e, ao mesmo tempo, interativa com as faculdades teóricas e de apetição.

Estabelecer e delimitar o princípio a priori do juízo reflexivo é marcar a base de sua atividade e, com isso, definir juízo reflexivo em geral. Em síntese, a faculdade do juízo reflexivo em geral, a nosso ver, tem por princípio a priori a harmonia do diverso, visto que sua atividade ocorre na multiplicidade dos fenômenos sem um conceito universal ou geral preestabelecido. Vejamos o que diz Kant na segunda introdução à Crítica da faculdade do juízo.

Ora, este princípio não pode ser senão este: como as leis universais têm o seu fundamento no nosso entendimento, que as prescreve à natureza (ainda que somente segundo o conceito universal dela como natureza) têm as leis empíricas particulares, a respeito daquilo que nelas é deixado indeterminado por aquelas leis, que se consideradas segundo uma tal unidade, como se igualmente um entendimento (ainda que não o nosso) as tivesse dado em favor de nossa faculdade de conhecimento, para tornar possível um sistema de experiência segundo leis da natureza particulares. Não como se deste modo tivéssemos que admitir efetivamente um tal entendimento (pois é somente à faculdade de juízo reflexiva que esta ideia serve de princípio, mas para refletir, não para determinar); pelo contrário, desse modo, esta faculdade dá uma lei somente a si mesma e não à natureza (KANT, 1995, p. 24).

Refletir, no sentido que o texto citado trata a expressão, dá-nos a ideia de que não implica determinar, isto é, conectar conceito e objeto. Refletir trata da experiência possível mesmo em meio a uma multiplicidade de fenômenos, em outras palavras da experiência coerente, de uma harmonia que possibilite a compreensão e de algum modo indique um sentido, uma teleologia. A reflexão não determina a natureza efetivamente, mas estabelece uma lei para si mesma, é simplesmente uma reflexão, não uma determinação. A reflexão, por não ser determinante, não liga um conceito a um objeto. Nesse caso, prescinde da existência efetiva do objeto, mas reflete sobre a razoabilidade e harmonia possível de uma pluralidade da natureza com o entendimento. Uma unidade refletida não é uma unidade determinada, mas possível.

objetivo nos falta totalmente uma lei ou um conceito de objeto que fosse suficiente, como princípio, para os casos que ocorrem (...) [A] faculdade do juízo reflexiva terá em tais casos que servir de princípio a si mesma: este - já que não é objetivo e não pode apresentar um fundamento de conhecimento suficiente para a intenção (Absicht) - deve servir como mero princípio subjetivo para o uso conforme a fins das faculdades de conhecimento, nomeadamente para refletir sobre uma espécie de objetos" (KANT, 1995, p. 227). 
Neste ponto de nossa análise é importante percebermos e indicarmos a localização que Kant confere a esta faculdade. A faculdade do juízo reflexionante é medianeira ${ }^{3}$ e está entre a faculdade teórica e a da apetição, articulando o livre jogo entre elas. A princípio, duas faculdades que tratam de domínios demarcados e distanciados por um abismo. Liberdade e natureza, razão e entendimento: uma relação difícil, um encontro estruturado em antinomias.

Só que na família das faculdades de conhecimento superiores existe ainda um termo médio entre o entendimento e a razão. Este é a faculdade do juízo, da qual se têm razões para supor, segundo a analogia, que também poderia precisamente conter em si a priori, se bem que não uma legislação própria, todavia um princípio próprio para procurar leis [...] (KANT, 1995. p. 21).

A faculdade do juízo reflexivo, no entorno do sistema crítico kantiano, opera uma espécie de ideia regulativa, que torna razoável e projeta como razoavelmente possível a unidade harmoniosa entre natureza e liberdade. Dumouchel(1994), em um texto primoroso sobre a gênese do juízo reflexivo de Kant, vê como elementos fundamentais para compreender o papel articulador da faculdade do juízo reflexiva, a relação entre três termos: reflexão, a faculdade de julgar e a finalidade (teleologia). "Pois a gênese da faculdade do juízo reflexionante não estará completa se não indicarmos como se produz a ligação entre a reflexão, a faculdade de julgar e a finalidade". ${ }^{4} \mathrm{~A}$ faculdade do juízo reflexionante tem o seu princípio a priori, como há pouco afirmamos, na harmonia possível dos múltiplos (de algum modo apontar isto, indica a interação entre reflexão, faculdade de julgar e finalidade). Contudo, Kant utiliza a expressão conformidade a fins para expressar esse princípio a priori da faculdade do juízo reflexivo. E fala também de uma conformidade a fins sem fim, ou seja, um fim como uma ideia regulativa, possível, não determinada como ocorre entre o entendimento e a natureza. Entretanto, ter como razoavelmente possível essa conformidade a fins já indica provável harmonia e encontro entre natureza e liberdade.

Ora, este conceito transcendental de uma conformidade a fins da natureza não é nem um conceito da natureza, nem de liberdade, porque não acrescenta nada ao objeto (da natureza), mas representa somente a única forma segundo a qual nós temos que proceder na reflexão sobre os objetos da natureza com o objetivo de uma experiência exaustivamente interconectada,

\footnotetext{
3 "La judiciaire, elle ne prescrit rien à la realité, comme le font l'entendement avec ses catégories et la sensibilité avec ses structures, elle ne prescrit rien à l'homme agissant; mais, située entre entendement et raison, reliée au príncipe de l'appréciation qu'est le sentiment du plaisir, elle pourra, précisément a cause de sa faiblesse quand il s'agit de commander, permettre d'élucider ce passage entre la théorie et la praxis, entre la connaissance et la décision, que constitue, s'il peut être justifié, le concept de la fin réalisée, de la finalité présente et immédiatement perçue" ( WEIL, 1970, p. 65).

4 "Mais la genèse de la faculté de juger réfléchissante ne sera complète que si l'on indique comment s'est produite la liaison entre la réflexion, la faculté de juger et la finalité." (DUMOUCHEL; 1994, p. 439).
} 
por conseguinte é um princípio subjetivo (máxima) da faculdade do juízo (KANT, 1995, p. 28).

É, a princípio, uma conformidade que se pressupõe entre a multiplicidade das leis da natureza, ou multiplicidade fenomênica da natureza com as leis do entendimento. Na parte VI da Introdução, Kant trata desse problema constatando a existência de uma multiplicidade fenomênica que ultrapassa as capacidades do entendimento, mas que requer ordem e harmonia entre este e esta multiplicidade, enfim uma relação das partes com um todo. Contudo, essa ordem e essa multiplicidade são articuladas pela faculdade do juízo, que, na realidade, nada acrescenta à natureza nem a ela prescreve regras, mas torna razoável e dá a condição a priori subjetiva para a unidade entre o entendimento e essa multiplicidade da natureza, entretanto, como possível e não como determinada (KANT,1995, p. 31). De fato, a faculdade do juízo reflexionante articula a possibilidade de uma harmonia da infinita particularidade fenomênica num todo, e de algum modo faz uma indicação de finalidade e, como já dissemos, de uma teleologia.

O conceito de uma coisa, enquanto fim natural em si, não é por isso um conceito constitutivo do entendimento ou da razão, mas, no entanto, pode ser um conceito regulativo para a faculdade de juízo reflexiva, para orientar a investigação sobre objetos desta espécie segundo uma analogia remota com a nossa causalidade segundo fins em geral, e refletir sobre o seu mais alto fundamento, o que não serviria para o conhecimento da natureza ou do seu fundamento originário, mas muito mais do conhecimento daquela nossa faculdade racional prática com a qual, por analogia, nós considerávamos a causa daquela conformidade a fins (KANT, 1995, p. 218).

Afirmamos há pouco, a partir da perspectiva e leitura de Dumouchel (1994), a necessidade de compreendermos a articulação entre reflexão, faculdade de julgar e finalidade para entendermos a gênese do juízo reflexionante. A noção de reflexão, na nossa análise do juízo reflexionante e, principalmente, na leitura política que Arendt faz deste, é de grande importância. Ao falarmos da reflexão, distinguindo-a da atividade judicativa de determinar, vemos que na ausência do universal, do conceito ao qual o objeto deveria ser subsumido, tem-se apenas a representação recebida do fenômeno, do meramente particular. A atividade reflexiva, portanto, volta-se para a representação dos objetos. Concentrando-se nessa representação, o refletir aponta a possibilidade do conceito, ou seja, a possibilidade do entendimento, de uma certa unidade em meio a uma grande multiplicidade de leis da natureza e de objetos particulares. A reflexão é uma comparação de representações sobre a produção de um conceito possível. ${ }^{5}$ Comparar represen-

\footnotetext{
5 "To reflect or consider is to hold given representations up to, and compare them with, either other representations or one's cognitive faculty, in reference to a concept that this [comparison] makes possible" (ALLISON, 2001, p. 45).
} 
tações ou percepções, sem a perspectiva de uma conexão de conceito e objeto, da subsunção de um particular a um universal, retira desta faculdade o ofício de produzir conhecimento, isto é, determinar. Esta faculdade apenas reflete. Importante:

Mas, porque na mera reflexão sobre uma percepção não se trata de um conceito determinado, mas de modo geral somente da regra para refletir sobre uma percepção em função do entendimento como uma faculdade dos conceitos; vê-se bem que em um juízo meramente reflexionante, imaginação e entendimento são considerados na proporção em que têm de estar no juízo em geral em relação um ao outro, comparada com a proporção em que efetivamente estão, em uma percepção dada (KANT, 1995, p. 56).

A preocupação de Kant, dada a constatação dessa imensa multiplicidade, que escapa à universalidade e à unidade do entendimento como faculdade teórica, é uma possível razoabilidade, uma ordem, uma harmonia entre os diversos, uma espécie de possibilidade de compreensão que dá unidade aos distintos domínios dessas faculdades e às antinomias. A apreensão da percepção, da representação, é exercida pela imaginação; sem um conceito já dado o que resta é um número imensurável de percepções, de possibilidades. Ora, como é possível a compreensão nestes termos, sem uma unidade? Como fôra dito anteriormente na afirmação de Kant, a faculdade do juízo não determina, isto é, não produz conhecimento, [..] em um juízo meramente reflexionante, imaginação e entendimento são considerados na proporção em que têm de estar no juízo em geral em relação um ao outro[...]. Constatada a inumerável diversidade das leis da natureza, da natureza que se especifica ${ }^{6}$, é buscado um jogo harmônico entre o entendimento e a imaginação. A reflexão, a comparação dessas representações diversas, ao apontar para a possível harmonia entre essas duas faculdades, lança luz para a possibilidade de uma razoabilidade no seio dessa diversidade, o que Kant entende como um sistema, uma unidade possível, que torna provável a comunicação e a compreensão dessas multiplicidades. Esta é a pressuposição do princípio a priori.

[...] é uma pressuposição transcendental subjetivamente necessária que aquela inquietante disparidade sem limite de leis empíricas e aquela heterogeneidade de formas naturais não convém à natureza, mas pelo contrário que esta, pela afinidade das leis particulares sob as mais universais, se qualifique a uma experiência, como sistema empírico (KANT, 1995, p. 45).

À semelhança da revolução copernicana, que Kant realizou na primeira Crítica, vemos aqui na faculdade do juízo reflexionante a condição dada a priori, subjetiva, para a possibilidade de uma unidade em relação à multiplicidade presente na natureza, que se especifica e escapa à universalidade.

${ }^{6}$ Cf. KANT, 1995, p. 51. 
Por fim cabe salientar, em função de nossa análise da leitura feita por Arendt desta faculdade, que a faculdade do juízo na ótica do desenvolvimento da crítica kantiana possui certa autonomia em relação às outras faculdades, e a esta autonomia Kant chama de Heautonomia7. É uma lei dada a si mesma por esta faculdade, sem determinar os objetos da natureza, mas uma lei que marca o próprio procedimento dessa faculdade. "[...] Portanto, ela própria deve indicar um conceito pelo qual propriamente nenhuma coisa é conhecida, mas que serve de regra somente a ela própria [...]" (KANT, 1995, p. 13, 29-30). Ora, esta lei, dada à faculdade do juízo por ela mesma, é dada a fim de refletir sobre a capacidade da natureza de se especificar, isto é, de especificar suas leis e apresentar com isso uma multiplicidade infinita, onde sem uma possível unidade, o conhecimento se encontraria em dificuldade para perceber a ordem que integra essas realidades ${ }^{8}$. A faculdade do juízo reflexionante, a partir de si, estabelece uma lei, não para determinar a natureza, mas para refletir sobre ela. E o princípio que fundamenta esse procedimento é o subjetivo a priori desta faculdade de juízo reflexionante, que pressupõe a concordância da natureza com a faculdade de conhecimento'. A faculdade do juízo reflexionante, a partir do seu princípio a priori, estabelece o procedimento para si própria, isto é, reflete sobre os múltiplos da natureza sem um conceito, tendo em vista a possibilidade dada a priori de uma conformidade a fins entre natureza e entendimento. É um procedimento restrito à faculdade do juízo, uma vez que estabelece este procedimento e esta perspectiva apenas para si própria, enfim, não determinando de forma objetiva os elementos e múltiplos da natureza, indicando apenas em caráter transcendental a sua possibilidade.

Assim, no início, quando tentamos apontar e esboçar o que se compreende por juízo reflexionante, obejtivamos tratar da especificidade desta faculdade, que é muito vinculada à perspectiva teleológica. Entretanto, a apropriação arendtiana dessa faculdade ocorre em seu uso estético. Ora, a dimensão estética do juízo reflexivo é um primeiro modo de abordagem do problema teleológico, dentro do quadro do sistema kantiano. Citando novamente Dumouchel (1994), notamos que Kant chega a essas perspectivas do juízo teleológico a partir de uma evolução de sua compreensão do juízo estético, ou juízo de gosto ${ }^{10}$. Contudo, não podemos negar que, em se tratando de especificação, de uma inumerável variabilidade que dificulta

\footnotetext{
${ }^{7}$ Sobre a heautonomia, cf. ALLISON, 2001, p. 41.

${ }^{8}$ Cf. (KANT, 1995, p.29).

${ }^{9}$ Cf. (KANT, 1995, p.29-30).

10 "Nous avons montré que la 'Critique du goût' possède une valeur heuristique intrasystémique indubitable dans la philosophie critique, dans la mesure où c'est précisément la réflexion sur la fondation transcendantale du goût qui a conduit à l'élargissement du projet critique, et qui a rendu possible, sous la forme d'une "critique de la faculté de juger", d'en espérer l'achèvement" (DUMOUCHEL, 1994, p. 440).
} 
grandemente uma possível unidade, falar sobre o gosto é de grande conveniência. Num primeiro momento, a análise do gosto indica a existência de um juízo reflexivo estético, que, no caráter reflexivo, possui uma dimensão teleológica. A inumerável variedade e a multiplicidade do gosto, a princípio incomunicáveis e caóticas, recebem um ordenamento e uma possibilidade de harmonia no princípio regulativo do sensus communis. Assim, enquanto reflexivo, o juízo estético evidencia também uma dimensão teleológica, uma possível comunicabilidade, uma harmonia do diverso dada como possível. De modo que enquanto juízo reflexionante, o uso estético desse juízo é guiado não necessariamente pelo gosto, mas sim pela teleologia.

[...] A problemática estética era assim retomada no interior de uma perspectiva teleológica geral renovada e dominada pela figura da faculdade do juízo reflexionante, do qual a reflexão estética não era doravante senão uma das especificações reflexivas. O conceito central da teoria estética de Kant, desde então, não é mais o "gosto", mas o "juízo reflexionante", do qual o gosto permanece somente um exemplo, mesmo se ele constitui aos olhos de Kant sua manifestação paradigmática (DUMOUCHEL, 1994, p. 420); (trad. e grifo nossos). ${ }^{11}$

Assim, o gosto apresenta-se como um objeto adequado a uma análise no âmbito desse horizonte de diversidade. Kant inicia, portanto, a terceira Crítica fazendo uma análise do juízo de gosto. Por ser este uso a base das análises arendtianas é que passamos agora a apresentar algumas características e particularidades desse uso, que julgamos importantes para compreendermos a apropriação que Hannah Arendt faz dessa faculdade, com objetivos de uma teoria política.

\section{A apropriação arendtiana do juizo reflexionante estético}

Neste ponto que agora iniciamos, partimos de uma primeira delimitação e determinação do que Kant compreende por juízo reflexivo, de forma a mostrarmos que, na própria compreensão da ideia de juízo reflexionante já se encontram características dessa atividade, que são muito interessantes para a determinação das categorias políticas arendtianas. Contudo, é sabido que Arendt se detém e cita várias vezes a sua apropriação do juízo

\footnotetext{
11 “[...] la problématique esthétique était ainsi reprise à l'intérieur d'une perspective téléologique générale renouvelée et dominée par la figure de la faculté de juger réfléchissante dont la réflexion esthétique n'était désormais que l'une des spécifications réflexives. Le concept central de la théorie esthétique de Kant, dès lors, n'est plus le 'goût', mais le 'jugement réfléchissant', dont le goût reste seulement un exemple, même s'il constitue aux yeux de Kant sa manifestation paradigmatique" (DUMOUCHEL ,1994, p. 420 , nota 3 ).
} 
reflexionante, mas não necessariamente do juízo reflexionante em geral, mas do juízo reflexivo em seu uso estético ou do juízo de gosto ${ }^{12}$. Sendo assim, vamos observar algumas peculiaridades desse juízo e iniciar uma leitura que nos possibilite visualizar o modo da apropriação feita por Arendt num intuito político ou, até mesmo, indícios que a "justifiquem".

\subsection{O juízo reflexionante estético}

Quando Kant se refere ao juízo reflexionante, ele aponta, como já dito, para dois modos desse juízo: o estético e o teleológico. Como alguns comentadores afirmam, o fundamento do juízo reflexionante é a finalidade. No entanto, para chegar a esta finalidade, isto é, à possibilidade de uma harmonia, de uma ordem, enfim de uma unidade projetada entre natureza e liberdade, o filósofo das Críticas inicia pelo juízo de gosto.

A nosso ver, iniciar pelo juízo de gosto indica começar por um campo envolto numa série de dificuldades de compreensão e harmonia. Afinal, o que poderia nos parecer como mais estritamente particular e de difícil conciliação que o gosto? Há uma harmonia possível na facticidade imensamente variável do gosto? Ter um conceito, estabelecer um conceito universal, ao qual submeter o gosto, constituir, em linguagem e compreensão kantianas, conhecimento a partir de sentimentos, enfim do gosto, seria uma tarefa marcada por contrasenso. Na realidade, Kant mostra aqui um primeiro nível da faculdade do juízo reflexionante, isto é, um primeiro nível de uma ideia regulativa de harmonia dos diversos. No caso do gosto trata-se da ideia de um sensus communis. Vimos que o princípio a priori do juízo reflexionante é a possibilidade dada subjetivamente da conformidade a fins sem fim (entenda-se a expressão fim sem fim como a possibilidade e não a determinação objetiva). Ora, Kant tenta mostrar, num primeiro momento da análise da faculdade do juízo reflexionante, como no seu uso estético está pressuposta a possibilidade de uma conformidade a fins dos inúmeros particulares, isto é, a possibilidade do belo. "Belo é o que apraz universalmente sem conceito" (KANT, 1995, p. 64).

Quando falamos da forma ou do modo de se chegar ao belo, isto é, no entorno de um juízo estético, estamos falando da possibilidade dada de nos entendermos sobre o que a princípio é de difícil conciliação, entendimento e comunicação, enfim de dar razoabilidade a um discurso dessa ordem. Entretanto, esta conciliação transita por um princípio a priori, que é condição de possibilidade dessa universalização, ou melhor, do poder reivindicar que outros aceitem ou cheguem a essa universalização. O juízo de gosto é assim definido por Kant:

Gosto, a faculdade de ajuizamento de um objeto ou de um modo de representação mediante uma complacência ou descomplacência independente de 
todo interesse. O objeto de uma tal complacência chama-se belo (KANT, 1995, p. 55).

O que ora vemos é a definição de um ajuizamento de gosto, ou estético, e, neste caso, o juízo de gosto é o ajuizamento de uma representação ou objeto, mediante uma complacência ou descomplacência. Grifamos esta passagem para destacar a base de análise do ajuizamento estético, a complacência, ou melhor dizendo, a satisfação independente de todo o interesse.

Surge aí para nós algo de fundamental para começarmos a perceber como esta faculdade atrai a atenção de Arendt num sentido político. Como ajuizar sobre um dado muito diverso, como é a satisfação, ou prazer e desprazer. Assim, o que Kant irá demonstrar é a existência de uma condição a priori na qual é fundada esta faculdade, a ponto de possibilitar uma comunicação e uma compreensão desse sentimento. Ou seja, o belo seria o que poderia ser reconhecido ou ajuizado a partir desse princípio a priori, com fundamento subjetivo e não objetivo ${ }^{13}$. É neste sentido que o filósofo fala da ausência de todo interesse, ou seja, daquilo que não é passível de se universalizar, do que não é a priori, não está dado na condição de possibilidade. O peculiar e importante nesta análise é que o juízo de gosto requer uma universalidade, ou uma possível comunicabilidade ${ }^{14}$ desse sentimento sem se fundar em um conceito ${ }^{15}$, isto é, sem determinação prévia, em sentido objetivo. Isso, dentro do contexto geral do juízo reflexivo, é indicação de uma teleologia, a comunicabilidade do gosto (algo diverso)

12 “[...] É essa capacidade de uma 'mentalidade alargada' que habilita os homens a julgarem; como tal, ela foi descoberta por Kant na primeira parte de sua Crítica do juízo, embora ele não reconhecesse as implicações políticas e morais de sua descoberta" (ARENDT, 2003, p. 299).

${ }^{13} \mathrm{O}$ fundamento da universalidade do gosto é subjetivo, ou seja, é dado a priori no sujeito e não no objeto, esse princípio subjetivo é o que possibilita a universalização ou a possibilidade de comunicação dos sentimentos de prazer ou desprazer. "Le jugement de goût, dans lequel nous avons conscience d'être tout à fait désintéressés, peut donc à juste titre réclamer une valeur universelle, quoique cette universalité n'ait pas son fondement dans les objets mêmes, en d'autres termes il a droit à une universalité subjective" (SOURIAU, 1926, p. 90). Cf. também, (KANT, 1995, p. 56 [\$6]).

${ }^{14}$ No dicionário de filosofia Abbagnano, verbete Gosto, vê-se: "Para Kant o gosto é uma espécie de senso comum, aliás, o senso comum no seu significado mais exato porque se pode definir como "a faculdade de julgar aquilo que se torna universalmente comunicável, sem a mediação de um conceito, o sentimento suscitado por uma determinada representação (Critica Facul. do juízo \$40). Portanto a universalidade do juízo de gosto não é aquela do juízo intelectual porque não se baseia no objeto, mas na possibilidade da comunicação com os outros. Em outros termos o juízo de gosto somente é universal porque se fundamenta na comunicabilidade. (ABBAGNANO, 1982, p. 463). Cf. também (KANT, 1995 , p. 137 [§39]).

${ }_{15}$ A fonte da universalidade do gosto não está fundada no conceito, "[...] Mais cette universalité n'a pas sa source dans des concepts. Car il n'y a point de passage des concepts au sentiment du plaisir ou de la peine [...]" (SOURIAU, 1926, p. 90) 
como possível. O juízo de gosto ajuíza segundo uma regra, que a própria faculdade judicativa se dá a si mesma, e, como já dito, ela é objeto de si mesma. É a forma a priori do ajuizar que é tematizada.

[...] é preciso convencer-se inteiramente de que pelo juízo de gosto (sobre o belo) imputa-se a qualquer um a complacência no objeto, sem contudo se fundar sobre um conceito (pois então se trataria do bom); e que esta reivindicação de validade universal pertence tão essencialmente a um juízo pelo qual declaramos algo belo [...] [U]ma universalidade que não se baseia em conceitos de objetos (ainda que somente empíricos) não é absolutamente lógica, mas estética, isto é, não contém nenhuma quantidade objetiva do juízo, mas somente uma subjetiva, para a qual também utilizo a expressão validade comum (Gemeingültigkeit) a qual designa a validade não da referência de uma representação à faculdade de conhecimento, mas ao sentimento de prazer e desprazer para cada sujeito. (KANT, 1995, p. 22-24)

$\mathrm{O}$ alcance dessa universalidade ou da comunicabilidade do sentimento de prazer ou desprazer passa, na argumentação kantiana, pelo jogo harmonioso das faculdades do conhecimento. Entretanto, essa harmonia não é uma tentativa de construir um conhecimento teórico, mas de poder comunicar o sentimento estético, o que a princípio é incomunicável, dada a suposta idiossincrasia do sentimento de prazer e desprazer. Afirma-se que essas faculdades têm entre si uma tensão ${ }^{16}$, e que, pelo juízo de gosto, elas são articuladas em razão da possibilidade de uma comunicabilidade.

O que se articula em função, de uma harmonia que ponha a priori a possibilidade da comunicabilidade dessa multiplicidade presente no sentimento de prazer e desprazer, e consequentemente um acordo no belo, é o jogo harmonioso entre imaginação e entendimento. Esse jogo harmonioso entre essas duas faculdades é a possibilidade de se estabelecer a comunicação entre os diversos. O que se busca é um sentido ou sensus communis, a fim de, a partir dele, poder se chegar a uma perspectiva estética, ou seja, no que se refere ao sentimento de prazer ou desprazer, a um ponto em que a multiplicidade possa ser comunicada, de modo a se chegar a uma unidade, neste caso estético, sobre o belo.

[...] e esta disposição não pode ser determinada de outro modo senão pelo sentimento (não segundo conceitos). Ora, visto que esta própria disposição tem que poder comunicar-se universalmente e por conseguinte também o sentimento da mesma (em uma representação dada), mas visto que a comunicabilidade universal de um sentimento pressupõe um sentimento comum[...] ( KANT, 1995, p. 84).

\footnotetext{
16 "[...] the 'friendship' between imagination and understanding is not without a certain tension, which results from the fact that they pull in opposite directions: the understanding toward universality and the imagination toward specificity" (ALLISON, 2001, p. 48).
} 
Enfim, o juízo de gosto tem como ponto alto a busca da possível comunicabilidade desse sentimento estético. Esta busca está, pois, alicerçada no jogo harmonioso entre imaginação e entendimento; entretanto, sem o amparo determinante do conceito. Na linguagem da crítica seria dizer uma conformidade a fins sem fim, isto é, sem uma determinação objetiva, sem interesse na existência objetiva de tal. O que se coloca é a possibilidade dada a priori, ou seja, subjetivamente. Uma conformidade a fins subjetiva, ou seja, sem a determinação de uma perfeição do objeto, ou até mesmo do caráter utilitário do objeto é, a nosso ver, de fundamental importância para as pretensões políticas de Arendt.

O formal na representação de uma coisa, isto é, a concordância do múltiplo com uma unidade (seja qual for), de modo nenhum dá por si a conhecer uma conformidade a fins objetiva; pois uma vez que se abstrai desta unidade como fim (o que a coisa deva ser), não resta senão a conformidade a fins subjetiva das representações no ânimo do que intui ; essa conformidade presumivelmente indica certa conformidade a fins do estado de representação no sujeito, e neste uma satisfação para captar uma forma dada na faculdade da imaginação, mas nenhuma perfeição de qualquer objeto, que aqui não é pensado por nenhum conceito de fim (KANT, 1995. p. 73).

Esta perspectiva que indicamos diz respeito, a nosso ver, à constante tentativa de Arendt de sair ou evadir-se de uma racionalidade instrumental que, na visão de nossa autora, desde os primórdios da filosofia política, já com Platão, invadiu e subverteu o sentido da política. A possibilidade de uma racionalidade que não seja instrumental, ao lidar com a pluralidade e articular suas tensões, nós a visualizamos na leitura que Arendt faz da crítica da faculdade do juízo de Kant.

Podemos então dizer que a crítica da faculdade do juízo reflexionante estético, apresentada por Kant, aqui tratada em linhas muito gerais, mostra características que estimulam Arendt a ver nela a possibilidade de se pensar uma racionalidade apta a tratar a política tendo à sua frente o horizonte da pluralidade, com as tensões que lhe são próprias e vitais. A faculdade do juízo reflexivo estético, que ora tentamos mostrar, articula uma indeterminação objetiva que, a nosso ver, soa como uma dimensão não instrumental. A leitura dessa faculdade kantiana tem como base a possibilidade pressuposta e projetada de uma comunicação através de um sensus communis, uma possibilidade anterior às individualidades idiossincráticas, a fim de se poder comunicar particularidades e entendê-las. Enfim, o poder e ter a capacidade de tematizar o particular são dado e característica dessa faculdade que desponta como um fator de grande importância para o trato e articulação das tensões do espaço público. Feitas estas análise e observações referentes à faculdade do juízo de Kant, nos deteremos em alguns pontos dos quais Arendt se apropria e ao seu modo a interpreta com um olhar político, mirando a pluralidade que, segundo ela, é a lei da terra, e neste caso apontando para a liberdade. 


\subsection{O status de apropriação}

Muitos questionamentos têm sido feitos, principalmente por parte de comentadores, em relação ao modo como Arendt se apropria e lê o juízo reflexionante estético de Kant. O fato é que Arendt afirma que este juízo é das faculdades focalizadas por Kant a mais política. "[...] Gostaria de me apoiar na primeira parte da Crítica do juízo, de Kant, que contém, enquanto 'Critica do juízo estético', talvez o maior e mais original aspecto da Filosofia Política de Kant" (ARENDT, 2003, p. 273).

Entretanto, Kant não a concebe e nem a compreende num sentido político. A faculdade do juízo reflexivo estético kantiano, de forma mais precisa a Critica da faculdade do juízo, é escrita com um cunho teleológico e numa forma de encenar um fechamento ou acabamento do sistema crítico por ele erigido. No entanto, Hannah Arendt não se posiciona numa perspectiva teleológica (ao modo como esta dimensão é abordada pela Crítica da faculdade do juízo), melhor, ela tenta evadir-se dessa ótica. Observando sua postura, em virtude de suas categorias básicas e fundamentais como a pluralidade, observa-se que ela não propõe desenvolver um sistema. Isto, a nosso ver, é tudo o que ela não pretende.

Arendt volta-se para a primeira parte da Crítica, isto é, detém-se no juízo estético. Em sua análise ela o desloca do quadro sistemático, em que essa faculdade se situa na filosofia crítica de Kant, para uma análise exclusivamente política. Partindo da compreensão de uma ruptura moderna com a tradição, ela se vê autorizada a se apropriar e reler, de forma autônoma, sui generis, conceitos já consagrados pela História da Filosofia. Sua metodologia nos permite ver, em sua obra, um apego à autonomia de pensamento, contra o mero exercício de erudição. Seu modo de análise e de apropriação pode ser assim expresso, em suas palavras: "[...] o fio da tradição está rompido, e temos de descobrir o passado por nós mesmos isto é, ler seus autores como se ninguém os houvesse jamais lido antes" (ARENDT, 2003, p. 257).

Hannah Arendt, dando-se liberdade hermenêutica ao se deparar com esse fio rompido, vê em diversos aspectos do juízo reflexionante estético características que lhe possibilitam estabelecer uma analogia com um possível juízo político. Um juízo político que considere e tenha como fundo o horizonte da pluralidade e as demais categorias que a acompanham. Nossa autora observa que Kant, ao descrever os juízos de gosto ou juízos estéticos, aponta para elementos que são profundamente políticos, enfim que se referem constantemente à dimensão e ao âmbito do público. $\mathrm{O}$ que em perspectiva arendtiana se infere disso é que há uma filosofia política não escrita em Kant e esta filosofia política não escrita estaria presente na Crítica da faculdade do juízo, e de forma mais precisa na sua primeira parte, ou seja, no juízo reflexionante estético. 
Uma vez que Kant não escreveu sua filosofia política, o melhor meio para descobrir o que ele pensava sobre o assunto é voltar-se para a Crítica do juízo estético, em que ao discutir a produção de obras de arte em sua relação com o gosto, que julga e decide sobre elas, confronta-se com um problema análogo (ARENDT, 1993, p. 79, grifo nosso).

Grifamos o termo análogo para apontarmos a direção e o modo como Arendt se apropria do juízo reflexionante estético de Kant. Um texto que julgamos de grande importância para essa justificativa é Crise da cultura, que consta no conjunto de ensaios de Hannah Arendt intitulado Entre o passado e o futuro. Neste texto, a autora trata da cultura e da arte (gosto), numa tentativa de aproximar arte e política, ou melhor, mostrar um lugar comum entre as duas. Entretanto, quando nos referimos à analogia, uma afirmação de Arendt pode parecer paradoxal: "Que a capacidade para julgar é uma faculdade especificamente política [...]" (ARENDT, 2003, p. 275). No contexto em que Arendt afirma esta frase, o cerne de sua argumentação é que o político ou o que confere à característica de político ao juízo é a dimensão do público, do mundo comum: "O elemento comum que liga arte e política é serem ambos, fenômenos do mundo público" (ARENDT, 2003, p. 272). Neste ensaio, nota-se uma organização das ideias que visa mostrar um conflito que afeta política e arte, em relação à ideia de cultura de massa e sociedade. $\mathrm{E}$ na afirmação da autora, trata-se de fenômenos datáveis, ou seja, modernos (ARENDT, 2003, p. 250). O que na realidade é mostrado neste ensaio é que a crise política e artística em relação à sociedade e a cultura está centrada num desmantelamento do público. A arte necessita de um espaço de aparência, um espaço público, assim como a política. Arte e política lidam com a necessidade de tornar comunicáveis o que individualmente se processa, ou seja, há a necessidade de se ajustar a um mundo comum.

A crise na cultura é esboçada como a perda ou degradação do mundo comum. O exame dessa degradação orbita em torno da perda da durabilidade, do perder a capacidade de deixar um legado (ARENDT, 2003, p. 257-264). A postura que se nota é a do consumo, uma atividade exclusiva do labor. O estabelecimento do comum encontra-se ameaçado pelo irresistível ciclo vital, que a tudo consome e devora. A durabilidade da cultura, o processo de criação de um mundo comum, o legado espiritual de uma geração subverte-se ao ser processado pela indústria da cultura de massas. Em lugar de uma produção de cultura, com durabilidade, produzse entretenimento, feito para ser consumido, o que, por suas características, não traz à tona a luminosidade de um mundo comum.

São dilemas que se agigantam aos olhos de Arendt, e é a partir deles que ela aproxima arte e política e se vê autorizada a encontrar nas características públicas do juízo estético características políticas. A seu modo, em uma analogia ela aproxima juízo estético e político. O dilema é esse:

Crer que tal sociedade há de se tornar mais "cultivada" com o correr do tempo e com a obra da educação constitui, penso eu, um fatal engano. $\mathrm{O}$ fato 
é que uma sociedade de consumo não pode absolutamente saber como cuidar de um mundo e das coisas que pertencem de modo exclusivo ao espaço das aparências mundanas, visto que sua atitude central ante todos os objetos, a atitude do consumo, condena à ruína tudo em que toca (ARENDT, 2003 , p. 264).

Arendt está decidida a afastar-se das posturas do animal laborans. Quando ela aponta para a perda da durabilidade, designa algo que fatalmente afeta o espaço público. $\mathrm{O}$ ato da fundação do espaço público visa conferir-lhe durabilidade, introduzir no público a dimensão do consumo, já que a relação instrumental de meios e fins provoca, na visão política de Arendt, a sua obliteração assim como a da arte. O que vemos, pois, é que essa aproximação de arte e política autoriza nossa autora a se apropriar do juízo estético de Kant, em razão de uma analogia possível entre essas realidades, por terem entre si um lugar comum.

\subsection{Elementos políticos da faculdade do juízo}

Quando afirmamos que Arendt identifica elementos políticos na faculdade do juízo reflexionante estético, podemos, então, nos perguntar: por que ela não vê ou não indica dimensões políticas na Crítica da razão prática? No ensaio que citamos (Crise da cultura), a autora tece uma justificação, mostrando que a princípio o que vemos na filosofia prática de Kant e em especial no imperativo categórico é a pressuposição não nova, mas antiga, de um acordo consigo mesmo.

Para vermos a faculdade do juízo em sua perspectiva apropriada e compreendermos que ela implica uma atividade mais política que meramente teórica, é mister recordar em poucas palavras o que habitualmente se considera como sendo a Filosofia Política de Kant, ou seja, a Crítica da Razão Prática, a qual trata da faculdade legislativa da razão. O princípio da legislatura, como estabelecido no "imperativo categórico - "age sempre de tal maneira que o princípio de tua ação possa se tornar uma lei universal" -, baseia-se na necessidade de pôr o pensamento racional em harmonia consigo mesmo (ARENDT, 2003, p. 274).

O que a faculdade do juízo estético, então, pressupõe não é pensar simplesmente em acordo com o eu, mas com o pensamento alargado "a fim de pensar no lugar de todas as demais pessoas" (ARENDT, 2003, p. 274) ) $^{17}$ E a esse respeito podemos, pelas palavras de Arendt, dizer ainda mais: de-

\footnotetext{
${ }^{17}$ Cf. também, na mesma obra, o ensaio Verdade e política: "Quanto mais posições de pessoas eu tiver presente em minha mente ao ponderar um dado problema, e quanto melhor puder imaginar como eu sentiria e pensaria se estivesse em seu lugar, mais forte será minha capacidade de pensamento representativo e mais válidas minhas conclusões finais, minha opinião" (ARENDT, 2003, p. 299).
} 
cidir "em antecipada comunicação com outros com quem sei que devo afinal chegar a algum acordo" (ARENDT, 2003, p. 274). Na análise de Arendt, o juízo repousa sobre um possível acordo com outrem. Arendt cita a propósito o $\S 40$ da Crítica. Entretanto, em vários momentos dessa obra, Kant afirma essa peculiaridade do juízo, ou seja, a pretensão do assentimento dos outros, mas simplesmente como pretensão e possibilidade, não como uma determinação, como em momentos anteriores já frisamos. "O juízo de gosto determina seu objeto com respeito à complacência (como beleza) com uma pretensão de assentimento de qualquer um, como se fosse objetivo" (KANT, 1995, p. 128, grifo nosso). O juízo não parte de generalidades, de universalidades predeterminadas, mas dos próprios particulares, essa é a sutileza do raciocínio político de Arendt. O juízo de gosto, nestes termos, não é impositivo como os juízos objetivos determinantes, ou seja, juízos cognitivos, pois "[...] não existe nenhum argumento empírico capaz de impor um juízo de gosto a alguém" (KANT, 1995, p. 131). Como dito, na visão de Arendt, entre o juízo estético e o juízo político há uma particularidade a mais que é o fato de serem persuasivos e não determinativos, pois o acordo é dado como possível, quer dizer, não é determinado, "eles têm em comum com as opiniões políticas o serem persuasivos" (ARENDT, 2003, p. 277) ${ }^{18}$.

Há um fato muito importante, a nosso ver, que contribui significativamente para tentarmos compreender a apropriação arendtiana da Crítica do juízo e não da Crítica da Razão prática. Nossa autora, ao identificar a faculdade do juízo como uma faculdade autônoma, de algum modo visualiza isso também em Kant. Contudo, a dimensão de autonomia que ela vê na faculdade do juízo se aplica a esse como uma faculdade política, tendo em vista a independência da política. Assim, a faculdade do juízo, como uma faculdade política, não dita a norma, não emite imperativos, mas ao contrário trata com possibilidades, com uma inumerável série de diferenciações, porém, com um acordo possível, não preestabelecido. Nessa situação a operação fundamental não é a operação legislativa ou imperativa da vontade, mas a reflexão, que está num terceiro uso da razão, a judiciária ${ }^{19}$. É dentro desse uso que Hannah Arendt então indica a possibilidade de uma filosofia política que leve em conta a questão da pluralidade, pois o juízo é uma faculdade distinta da vontade e sendo assim distinto da razão prática.

Pois o julgamento do particular - isso é belo, isso é feio; isso é certo, isso é errado - não têm lugar na filosofia moral Kantiana. O juízo não é a razão prática; a razão prática "raciocina" e diz o que devo e o que não devo fazer;

\footnotetext{
${ }^{18}$ Cf. KANT, 1995, p. 83.

${ }^{19}$ A forma como Eric Weil traduz o título da terceira crítica (Crítica da Judiciária), dá o tom desta distinção em relação à razão prática. A judiciária indica um terceiro uso da razão, distinto do agir e do conhecer. Cf. PERINE, 1987, p. 74, nota 23.
} 
estabelece a lei e é idêntica à vontade, e a vontade profere comandos; ela fala por meio de imperativos. O juízo, ao contrário, provém de um "prazer meramente contemplativo ou satisfação inativa [untätiges Wohlgefallen] (ARENDT, 1993, p. 22-23).

Ainda justificando o fato de se perceberem dimensões políticas na Crítica da faculdade do juízo e não na Crítica da razão prática, um dado que soa forte para Arendt é a forma como Kant, no entender de nossa autora, direciona a Crítica. Na segunda Crítica, Kant fala da razão prática como uma faculdade para todo o ser racional; entretanto, na Crítica da faculdade do juízo ela visualiza em Kant uma orientação voltada não para todo o ser racional, mas especificamente para o homem (ARENDT, 1993, p. 21-37). E, na ótica arendtiana, a terceira Crítica dirige-se aos seres plurais que estão na companhia uns dos outros ${ }^{20}$, são marcados por sentimentos e são dotados de um sensus communis. Nas palavras de Kant podemos visualizar a possibilidade dessa interpretação e apropriação de Arendt.

Amenidade vale também para animais irracionais; beleza somente para homens, isto é, entes animais, mas contudo racionais, mas também não meramente enquanto tais (por exemplo, espíritos), porém ao mesmo tempo enquanto animais; o bom, porém, vale para todo ente racional em geral (KANT, 1995, p. 54-55).

Quando Arendt, então, foca e destaca esta indicação kantiana, a sua apropriação está direcionada para o sentido da política no horizonte da pluralidade. Esse falar do homem não como meramente racional, mas como homens, isto é, que se especificam, e mais precisamente instauram e estão em pluralidade, é a base da análise de Hannah Arendt.

Quando falamos da pluralidade, a ideia fundamental é a compreensão do particular (ARENDT, 1993, p. 119-120) gestado neste contexto de pluralidade. Com efeito, Kant fala de uma pluralidade fenomênica numa natureza que se especifica. É dentro desse ambiente e da possibilidade do novo e inaudito, ligados à natalidade, isto é, essa especificação ou individuação do Homem em homens, que o particular faz sentido numa direção política, no contexto do pensamento arendtiano. As ações, numa compreensão política de Arendt, estão marcadas por essas características dos homens no plural, a natalidade, o fato de serem especificamente particulares, plurais. $\mathrm{Na}$ medida em que estão fora das relações necessárias e previsíveis da causalidade, eles são contingentes e, assim, livres: "[...] a faculdade do juízo lida com particulares que, como tais contêm algo contingente em relação ao

\footnotetext{
20 "A primeira poderia ser sumariada, ou melhor, indicada, como a "sociabilidade" do homem, isto é, o fato de que nenhum homem pode viver sozinho, de que os homens são interdependentes não apenas em suas necessidades e cuidados, mas em sua mais alta faculdade, o espírito humano, que não funcionaria fora da sociedade humana. Companhia é indispensável para o pensador" (ARENDT, 1993, p. 18).
} 
universal" (ARENDT, 2000, p. 370). Afirma-se com isso mais uma evidência da importância do juízo reflexionante em seu uso estético, para Arendt, ou seja, o fato de lidar com particulares.

Quando Arendt fala e analisa a ação e seu caráter de imprevisibilidade, está se referindo à ação neste horizonte marcado pela pluralidade e natalidade do homem, ou seja, à faculdade de iniciar algo novo. O evento, como já afirmamos, é um dado que escapa às previsibilidades, ao determinismo do conceito, do universal. A possibilidade do iniciar coloca em foco que, no âmbito da ação, no espaço público, um espaço que é comum (salvo diferenças específicas dessas atividades) à arte e à política, há a necessidade de uma faculdade que esteja apta a se relacionar com os particulares, com os novos que adentram o mundo, sem subjugá-los a uma uniformização ou universalização, próprias das faculdades teóricas. O que Arendt busca é uma faculdade que tenha habilidade para tratar, de início, com a imprevisibilidade (característica da ação); que vise, então, abrir-se para a tensão que não se elimina, em função da pluralidade e da natalidade. Assim, as pretensões levantadas, sejam as do acordo, sejam as da compreensão possível de um evento, são postas como possibilidade, e não como predeterminadas.

Arendt identifica em Kant um aceno à condição plural do homem. O gosto é uma faculdade que se exerce em sociedade, e sociedade, nesse contexto, não tem a conotação dada por Arendt, pois significa ser exercitado em coletividade, em meio a outros, no tentar e pretender fazer-se entender pelos outros "[...] quando julgamos, julgamos como membros de uma comunidade" (ARENDT, 1993, p. 93). A pluralidade no gosto constitui-se tanto no estar entre os homens, como também pela imensurável possibilidade advinda da liberdade criativa dos gênios. Este estar em comunidade para Arendt é importante, pois indica sair do isolamento, enfim, propor a possibilidade de uma atividade que se exerça tendo em vista o estar com e entre os outros. É uma tendência que apresenta as marcas e perplexidades do totalitarismo, principalmente em relação ao isolamento provocado por esta forma degenerada de política (ARENDT, 1998, p. 590), e que de algum modo se mantém como um risco possível diante das sociedades de massa. Kant, ao falar do juízo estético, dá a entender ser a comunidade seu locus de exercício.

Empiricamente o belo interessa somente em sociedade; e se se admite o impulso à sociedade como natural ao homem, mas a aptidão e a propensão a ela, isto é, a sociabilidade, como requisito do homem enquanto criatura destinada à sociedade, portanto como propriedade pertencente à humanidade, então não se pode também deixar de considerar o gosto como uma faculdade de ajuizamento de tudo aquilo pelo qual se pode comunicar mesmo o seu sentimento a qualquer outro, por conseguinte como meio de promoção daquilo que a inclinação natural de cada um reivindica (KANT, 1995, p. 143). 
Outro elemento que atrai Arendt e possibilita uma analogia com um possível juízo político é a comunicabilidade, principalmente vista a partir da percepção de que o juízo se exerce em comunidade. Para tal, Kant aponta para um fato que politicamente é de grande importância para Arendt, principalmente em sua teoria política pautada pela pluralidade e natalidade. A característica que destacamos é a comunicabilidade e seu pressuposto de desinteresse ${ }^{21}$.

No destaque feito acima e na citação extraída da Crítica da faculdade do juízo de Kant, vimos que ao final o filósofo enfatiza e delimita uma compreensão de gosto, como uma faculdade de ajuizamento de tudo aquilo pelo qual se pode comunicar, mesmo o seu sentimento a qualquer outro. Esse aspecto da faculdade do gosto de poder comunicar aos outros e fazer a pretensão de um acordo comum é, em termos políticos, de grande importância para Arendt.

Como já vimos, o espaço público é marcado por uma pluralidade, é o espaço da palavra e da ação. A ação é essencialmente marcada pela natalidade própria de seu agente, enfim por uma pluralidade que a coloca na via da imprevisibilidade. Assim como o gênio necessita do gosto, como uma medida que lhe possibilita comunicar e dar a conhecer a sua atividade criativa aos outros, assim também a absoluta novidade que é o homem, ao executar a ação tem necessidade também de um sentido comum que a torne comunicável e até possível de ser consensuada, saindo com isso de um ciclo de idiossincrasia, individualismo e incompreensão. O que é vital neste processo é o estar conectado com um comum entre os homens, com uma realidade que, ainda que vista de posições diversas, seja comum, compartilhada: "O julgamento é uma, se não a mais importante atividade em que ocorre esse compartilhar-o-mundo" (ARENDT, 2003, p. 276).

Ademais, há um outro elemento na vida política que se liga, e muito, com essa tendência e pressuposição de comunicação presente no juízo de gosto: é o fato de que no falar, no discurso, o agente revele o seu quem (who). Como tornar esse quem comunicável? Esta pergunta está aos olhos de Arendt, na mesma linha da reivindicação do juízo de gosto de tornar comunicável os sentimentos estéticos, ou seja, o prazer e o desprazer. Além disso, o discurso, a fala, o contar a história, da perspectiva do espectador desinteressado, daquele que não é afetado pela passionalidade do ator, requer essa medida de comunicabilidade, e, mais ainda, como Kant já indicava no juízo de gosto, um certo desinteresse. O contar a história con-

21 "O próprio processo de formação de opinião é determinado por aqueles em cujo lugar alguém pensa e utiliza sua própria mente, e a única condição para esse exercício da imaginação é o desinteresse, a liberdade dos interesses privados pessoais" (ARENDT, 2003, p. 299). 
fere sentido, significado; entretanto, essa postura do espectador é fundamentalmente, na forma como Arendt a descreve, uma postura desinteressada, enfim, sem idiossincrasias e passionalidade.

O que ele vê é o que mais conta; ele pode descobrir um sentido no curso tomado pelos eventos, um sentido ignorado pelos atores; e o fundamento existencial para o seu vislumbre é o desinteresse, sua não participação, seu não envolvimento (ARENDT, 1993, p. 17) ${ }^{22}$.

O olhar do espectador, com todas essas características do juízo já descritas, é um olhar desinteressado, portanto desprovido da relação meios e fins. É o modo arendtiano, de certa forma, amparado no juízo reflexionante estético de Kant, de tematizar a aparência sem conferir-lhe necessariamente um status de primazia. Essa é uma constante tentativa de Arendt com o propósito de resgatar o sentido da política, isto é, sair da ótica legada pela tradição da filosofia política de pensá-la no âmbito da fabricação. A tentativa de sair desse ciclo de meios e fins, uma forma de tematizar a aparência sem um status de primazia, é o olhar desinteressado do juízo sem determinar um fim. Portanto, ser e aparência podem de algum modo coincidir.

No ato de recontar a história há um desvelamento de sentido e significado, mas não uma determinação de fim ou utilidade. Ser e aparecer coincidem na identificação entre storyteller e espectador. Quando o storyteller rememora e reconta a história, como representação, isto é, coloca-a em uma situação onde é possível sobre ela refletir, e daí como espectador olhar sem ser necessariamente e objetivamente afetado, tem-se um olhar desinteressado, o olhar do espectador. É nesse sentido que ser e aparecer podem coincidir: a aparência na representação é passível de desvelamento de sentido sem a parcialidade do ator afetado, sem um fim predeterminado. $\mathrm{O}$ desinteresse, ao postular a possibilidade da comunicação de um sentido e significado desvelado, também põe essa representação sob a égide da liberdade, isto é, livre de uma determinação instrumental objetiva. Com isso, visualiza-se essa coincidência distinta, ao modo de uma constante tensão, conciliar mantendo diferenças. É no recontar, no pôr em representação, que o espectador visualiza sentido (ARENDT, 2000, p. 378).

O desinteresse presente nestas atividades é uma marca do juízo estético kantiano. Ele se apresenta, aos olhos de Arendt, como uma característica que torna viável e motiva a sua busca por esse sentido da política, que se mostra alheio à relação instrumental, ou baseada na ideia da fabricação de meios e fins. Um juízo desinteressado é aquele fora dessa relação; o olhar do espectador é "um olhar por olhar [...] mais fascinados pelo espetáculo

\footnotetext{
${ }^{22}$ Cf. ARENDT, 2000, p. 374.
} 
em si" (ARENDT, 2003, p. 273). Ora, esse tipo de ajuizamento, na visão com que estamos lendo a apropriação de Arendt, aparece insinuado no juízo estético de Kant. O juízo estético de Kant possui uma conformidade a fins sem fim, isto é, não há determinação e sim uma possibilidade; o juízo de gosto lida com o sentimento de prazer e desprazer gerado por uma representação, e mais, não define nenhuma perfeição de objeto, ou seja, é sim um olhar desinteressado.

[...] essa conformidade presumivelmente indica certa conformidade a fins do estado da representação no sujeito, e neste uma satisfação para captar uma forma dada na faculdade da imaginação, mas nenhuma perfeição de qualquer objeto, que aqui não é pensado por nenhum conceito de fim. Como, por exemplo, quando na floresta encontro em relvado, em torno do qual as árvores estão em círculo e não me represento aí um fim, ou seja, de que ele deva porventura servir para a dança campestre, não é dado pela simples forma o mínimo conceito de perfeição (KANT, 1995, p. 73).

Aqui poderíamos indicar, pois, um ponto em que a analogia de Arendt se faz visível. Tanto o juízo estético como o juízo pretendidamente político vão se posicionar diante de elementos que possuem um fim em si mesmos. A arte na perspectiva kantiana, como já evidenciamos, possui um fim em si e não está ligada a uma ótica de utilidade nem mesmo de uma finalidade instrumental. Seguindo este raciocínio, podemos fazer referência à ação, objeto de juízo da atividade judicativa política, pois a ação, no contexto do pensamento de Arendt, também é compreendida como um fim em si mesma. Tanto a atividade estética, como a atividade da ação são, pois, marcadas por um estado de liberdade. O que a atitude do desinteresse, na articulação estética kantiana, indicará, é uma possível lucidez a partir da possibilidade de se estar conectado com a realidade a partir do sensus communis. Em Arendt, essa possibilidade de conectar-se com a realidade, ou melhor, a um mundo comum, é de fundamental importância, principalmente em relação à postura de introspecção da era moderna, que em alguns momentos ela chama de alienação do mundo, isto é, a perda cada vez maior da realidade pela perda do mundo comum (ARENDT, 1997, p. 296-297). Uma racionalidade pautada nessa introspecção e previsibilidade perde-se do horizonte político, e submete à violência as ações e tendências imprevisíveis da atividade política.

A pretensão é ver no juízo a possibilidade, ao se falar de sua comunicabilidade e de um sensus communis (este sensus communis dá a possibilidade de serem compreendidas e adquirirem sentido sem serem idiossincraticamente incomunicáveis às novidades advindas da ação), de propor uma relação que não se perca da realidade. Ora, perder a realidade em termos arendtianos implica sair da pluralidade, imergir na solidão, no isolamento e na absoluta introspecção, marcas da era moderna e ademais experimentadas pelos regimes totalitários. Um risco que ronda os homens de pensamento, os filósofos profissionais. A este propósito, Arendt faz 
uma interessante comparação do juízo estético como um sensus communis, com a phrónesis grega (ARENDT, 2003, p. 275). A comparação é de um senso que nos mantém ligados à comunidade dos homens, uma espécie de "ethos, como uma capacidade mental extra [...] - que nos ajusta a uma comunidade. O entendimento comum dos homens ... é o mínimo que se pode esperar de qualquer um que se diga homem" (ARENDT, 2000, p. 379).

Este sensus communis alcançado pelo exercício do desinteresse é um exercício de abstenção das idiossincrasias, ou seja, tenta-se chegar a um geral e, sendo geral, possível de ser comunicado. É bom ter em mente que este geral do juízo não é um universal dado, como no juízo determinante de cunho teórico. Este geral é de cunho reflexivo, ou seja, tem-se apenas o particular ou os particulares, e, por meio da reflexão sobre a representação, atingir um geral, ou seja, em linguagem kantiana, uma aproximação da liberdade da imaginação com a ordem do entendimento, a fim de torná-lo comunicável aos outros. Pensar dessa maneira, em termos arendtianos, e também kantianos, é falar de uma mentalidade alargada, isto é, este geral é o pensar no lugar do outro, projetar e representar por meio da imaginação a possível visibilidade do outro em função de tal representação. $\mathrm{O}$ pensar alargado é um pensar com os outros por representação, não é conformar-se aos outros, mas tornar as ideias, a liberdade criativa, comunicável, dar ao indizível das ideias o caráter de comunicabilidade. É, a nosso ver, o ensaio de uma possível racionalidade intersubjetiva, é uma racionalidade que oferece uma precondição para o discurso na cena pública, que não perde a presença constante e possível dos outros: o estar com os outros é a garantia da realidade. É no pensar alargado que se decide o que deve ou não ganhar publicidade, ou seja, o que pode ser e é passível de comunicação no mundo público. Esse caráter de definir o que deve ou não vir a público, dentro dessa situação da mentalidade alargada, isto é, pensar no lugar e com o outro implica ter presente uma visão de mundo, o que é a realidade.

Em primeiro lugar, ouvimos distintamente que é a polis, o domínio da política, quem determina os limites ao amor à sabedoria e à beleza, e visto que, como sabemos, os gregos pensavam ser a polis e a "política" (e de modo algum realizações artísticas superiores) o que os distinguia dos bárbaros, devemos concluir que tal diferença era também 'cultural', uma diferença do seu modo de relacionamento com coisas "culturais", atitude diversa ante a beleza e a sabedoria, as quais só poderiam ser armadas dentro dos limites impostos pela instituição da polis (ARENDT, 2003, p. 268).

Arendt observa, em nota, ao citar a semelhança entre o juízo e a phrónesis, que em Aristóteles distinguem-se dois tipos de sabedoria: a do sábio filósofo e a do sábio político (ARENDT, 2003, p. 274) ${ }^{23}$. O que queremos des-

\footnotetext{
${ }^{23}$ Cf. ARENDT, 2003, p. 274, nota 14.
} 
tacar é, pois, que o sentido de se falar da phrónesis tem lucidez, ao se pressupor o contexto da polis: o partilhar um mundo comum, um sensus communis, uma realidade que é feita no estar com os outros. O sensus communis, ao estar ligado à atividade judicativa que permite ser compreensível ou dá a possibilidade de vir a público, implica sim um mundo partilhado no qual o belo faz sentido e o político ganha significado, e é até possível a sua aceitação. Indica-se, com isso, que o sensus communis é também plural, ele não se refere ao Homem, mas aos homens.

Enfim, o que é público é iluminado nessa atividade do pensar alargado. Distingue-se o que é público e o que é privado, e assim o que pode ou não adentrar a esfera pública. É um ensaio de uma racionalidade intersubjetiva, pois estabelece uma condição, um pressuposto que é necessário para o debate e diálogo na esfera pública, em que questões de ordem privada e mesmo da intimidade não são temas nem objetos passíveis de comunicabilidade, dadas as idiossincrasias e o alto grau de envolvimento e passionalidade.

O pensar alargado não é uma conformação, mas precondição intersubjetiva para o debate, e desenvolvimento das tensões da arena pública. É a projeção de um possível acordo, porém, sempre ameaçado e marcado pela constante possibilidade efetiva de um desacordo, de uma novidade, de um novo início, e que, pela conexão ao sensus communis à realidade, torna-se passível de comunicação, entendimento e até de convencimento no desenrolar vital do debate público.

\section{Considerações finais}

O percurso feito em torno da apropriação arendtiana da faculdade do juízo kantiana teve como meta elucidar que, no contexto da obra da autora, esta apropriação é detentora de sentido e não se configura como um absurdo filosófico.

Quando Hannah Arendt apropria-se da faculdade do juízo kantiana ela se ampara no tom desconstrutor da filosofia contemporânea da qual é herdeira. Ela desconstrói uma interpretação canônica do texto de Kant e traz à luz uma outra possibilidade hermenêutica do texto. Seu horizonte é o fio rompido da tradição, e é isso que lhe permitiu a audácia hermenêutica, movida pelos apelos de uma reflexão inserida no pulsar dos dilemas de seu tempo, não tão distante de nós.

No contexto da obra de Hannah Arendt, a perda da realidade, a desconexão com o real constituído pela vida pública, principalmente ilustrado pelo fenômeno do totalitarismo, traz à tona a necessidade de se articular uma 
faculdade que não perca e nem se desvincule de um mundo comum “ real", de modo que, para a autora, fenômenos como a banalidade do mal e o vazio de pensamento possuem vínculos significativos com estas circunstâncias, sendo pois a faculdade do juízo requerida como algo mais que necessário frente a este risco que ronda a vida moderna.

A leitura arendtiana da faculdade do juízo ajusta-se na totalidade da obra da autora e, ao percorrer a diversidade de seus textos, como se fez aqui, percebe-se como o conceito foi pouco a pouco sendo forjado, na medida em que as questões políticas ganhavam densidade e complexidade. A autora viu na faculdade do juízo, presente na obra de Kant, um aspecto político que se ajustava às suas indagações e preocupações; ela não faz uma hermenêutica da obra de Kant, mas se apropria de conceitos estéticos kantianos alinhados às características da vida pública e suas relações com a vida contemplativa. Se não olharmos a relação entre a vida ativa e a vida contemplativa, não veremos a coerência da faculdade do juízo na obra de Arendt.

No contexto dos escritos políticos de Hannah Arendt há uma série de concepções que desenham um espaço que exige a faculdade do juízo. Dentre esses conceitos sobressai a ideia de sociedade tal como ocorre na modernidade e o consequente fenômeno de alienação do mundo. Esses conceitos, muito articulados na Condição Humana, já apontam para o fato de que uma faculdade do juízo tal como ela a desenha é algo fundamental no jogo das estruturas políticas do pensamento arendtiano.

Assim, publicidade é, pois, elemento regulador da atividade livre da política, ou seja, sem a determinação de fins preestabelecidos, isto é, sem uma determinação moral. É o modo arenditano de preservar a imprevisibilidade e liberdade da ação. Poder tornar-se público, poder ser divulgado e comunicado é o critério regulativo da atividade política. O juízo é neste contexto, como em Kant, uma atividade mediadora, porém aqui sua mediação é entre o pensamento e a ação. Ele mantém o pensamento conectado à realidade e à ação, abre a possibilidade de sentido e significado. É a luz deste elo, que com ela podemos afirmar que o pensar traz ganhos para a coisa pública.

Conclui-se portanto que, na obra de Hannah Arendt, o espaço público é um espaço de tensões: dos particulares, das opiniões diversas, de uma atividade mediada pela fala sem um fim predeterminado. O juízo no jogo interno da obra da autora enfrenta as tensões, ao se deter sobre os particulares e ao conduzir a uma mentalidade alargada que, em síntese, implica ter representado os outros no julgar. O juízo também estabelece a possibilidade de um critério para a consideração, comunicação e articulação dos particulares e do processo público de formação da opinião. O critério do juízo não é a verdade do filósofo, mas a mentalidade alargada, o ter os 
outros representados. O juízo ao articular, pensar e agir, isto é, ao manter o pensamento em contato com a realidade possibilita a "realização" do pensamento no espaço da aparência. E isso pode trazer ganhos para a coisa pública. A articulação desta faculdade é a pedra de fecho das demandas políticas de Arendt que caminham para um ajuste de contas entre o pensar e a ação, entre a vida contemplativa e a vida ativa.

\section{Referências}

ADEODATO, João Maurício Leitão. O problema da legitimidade - no rastro do pensamento de Hannah Arendt. Rio de Janeiro: Forense Universitária, 1989.

AGUIAR, Odílio Alves. Filosofia e política no pensamento de Hannah Arendt. Fortaleza: UFC, 2001.

ASSY, Bethânia. Hannah Arendt e a dignidade da aparência. In: DUARTE, André et al (org.). A banalização da violência: a atualidade do pensamento de Hannah Arendt. Rio de Janeiro: Relume Dumará, 2004. p. 161-171.

ABBAGNANO, Nicola. Dicionário de filosofia. São Paulo: Mestre Jou, 1982.

ALLISON, Henry E. Kant's theory of taste - a reading of the critique of aesthetic judgment. Cambridge: University Press, 2001.

ARENDT, Hannah. A vida do Espírito. Trad. Antônio Abranches et al. Rio de Janeiro: Relume Dumará, 2000.

. A condição Humana. Trad. Roberto Raposo. Rio de Janeiro: Forense Universitária, 1997.

\section{4.}

. The Human condition. Chicago: The University of Chicago Press,

. Lições sobre a filosofia política de Kant.Trad. André Duarte. Rio de Janeiro: Relume Dumará, 1993.

. Lectures on Kant's political philosophy. Chicago: The University of Chicago Press. 1992. p 89-157.

A dignidade da política. Trad.Antonio Abranches et al. Rio de Janeiro: Relume Dumará, 1993.

.As Origens do Totalitarismo. Trad. Roberto Raposo. São Paulo: Companhia das Letras, 1998

. Da Revolução. Trad. Fernando Dídimo Vieira. São Paulo; Brasília: Ática; UnB, 1988. 
. Da Violência. Trad. Fernando Dídimo Vieira. Brasília: UnB, 1990.

. Entre o passado e o futuro. Trad. Mauro W. Barbosa. São Paulo: Perspectiva, 2003.

Homens em tempos sombrios. Trad. Denise Bottman. São Paulo: Companhia das Letras, 1987.

Compreensão e política e outros ensaios. Trad. Miguel Serras Pereira. Lisboa: Relógio D'Água, 2001.

. Compréhension et politique. In: Esprit, p. 66-79. juin 1980

1999.

Crises da República. Trad. José Volkmann. São Paulo: Perspectiva,

Eichmann à Jerusalém. Rapport sur la banité du mal. Traduction de l'anglais par Anne Guérin. Paris:Gallimard, 1997.

. Love the Saint Augustine. Chicago: The University Press, 1996.

O conceito de amor em Santo Agostinho. Trad. Alberto Pereira Dinis. Lisboa: Instituto PIAGET, 1997.

O que é Política? Fragmentos de obras póstumas compiladas por Ursula Ludiz. Trad. Reinaldo Guarany. Rio de Janeiro: Bertrand Brasil, 2002.

. Marx and western political Thought. In: Social Research, vol. 69, n. 2, p. 273-319, Summer 2002. Spring 1990.

Philosophy and Politics. In: Social Research, vol. 57, n. 1 p. 73-103,

CORREIA, Adriano (org.). Transpondo o abismo: Hannah Arendt entre a filosofia e a política. Rio de Janeiro: Forense Universitária, 2002.

DUARTE, André. O pensamento a sobra da ruptura: política e filosofia na reflexão de Hannah Arendt. São Paulo: Paz e Terra, 2000.

DUMOUCHEL, Daniel. La découverte de la faculté de juger réfléchissante. In: Kant- Studien, 85, p. 419-442, 1994

KANT, Immanuel. Crítica da faculdade do juízo. Trad. Valério Rohden e António Marques. Rio de Janeiro: Forense Universitária, 1995.

Crítica da razão prática. Trad. Valério Rohden. São Paulo: Martins Fontes, 2002.

Duas introduções à crítica do juízo. Org. Ricardo Terra. São Paulo: Iluminuras, 1995. 
Fundamentação da metafísica dos costumes. Trad. Paulo Quintela. São Paulo: Abril Cultural, 1974.

LAFER, Celso. O sopro do pensamento, o peso da vontade e o espaço público do juízo: dimensões filosóficas da reflexão política de Hannah Arendt. In: Revista Brasileira de Filosofia, vol. 30 n. 114, p. 184-200, 1999.

A reconstrução dos direitos humanos: um diálogo com o pensamento de Hannah Arendt. São Paulo: Companhia das Letras, 2003.

MORAIS, Eduardo Jardim; BIGNOTTO, Newton. Hannah Arendt. diálogos, reflexões, memórias. Belo Horizonte: UFMG, 2001.

PERINE, Marcelo. Filosofia e violência. São Paulo: Loyola, 1987.

SOURIAU, Michel. Le jugement réfléchissant dans la philosophie critique de Kant. Paris: Librairie Félix Alcan, 1926.

WEIL, Eric. Problémes Kantiens. Paris:Vrin, 1970.

Endereço do autor:

Rua Olinda Martins D'Antonino, 126 - Apto. 102

36570-000 Viçosa - MG

e-mail: geralemery@hotmail.com geraldo.emery@ufv.br 